This is an accepted manuscript version of an article published by Taylor and Francis. http://journalauthors.tandf.co.uk/preparation/copyright.asp 


\title{
How Losers Can Turn into Winners in Disputatious Public Policy: A Heuristic for Prospective Herestheticians
}

\begin{abstract}
The study of heresthetic is a quest to explain how potential political losers might become winners. Local Government amalgamation is invariably a controversial and hotly contested political decision. It thus represents the ideal context to locate a pedagogical discussion regarding how clever herestheticians might act to bring about unlikely political success. Specifically, we extend the heresthetic literature by drawing attention to the costs (opportunity, contingency and legacy costs) inherent to various strategies, the need to carefully evaluate the heresthetic potential of different dimensions according to which amalgamations might be argued, and the importance of ensuring that the rhetorical seasoning is appropriate. This leads us to propose a heuristic that we argue has the potential to turn losers into winners on the vexed matter of local government amalgamations. We conclude by considering the implications of our heuristic for both prospective herestheticians in other public policy areas and for the wider heresthetic research agenda.
\end{abstract}

Keywords: heresthetic, Local Government amalgamation, dimensions, costs 
Heresthetic is the art of exploiting latent attitudes of an audience in such a way that potential losers might become winners (Riker 1986). It differs fundamentally from rhetoric which is 'the faculty of defining in any given case the available means of persuasion' (Aristotle 2012, 8). That is, the heresthetician manipulates along existing tastes and preferences - often by re-casting the debate in terms of alternate salient dimensions - rather than trying to change tastes and preferences. Indeed, the etymology of Riker's $(1986 ; 1996)$ neologism is most instructive: Heresthetic is derived from the classical Greek haireomai which means 'to choose... a self-willed opinion... which is substituted for the submission to the power of truth, and leads to division and formation of sects' (Vine 1940). The root word is recognisable in our English term 'heresy' which likewise denotes an opinion contrary to that which is commonly held. Thus, a person practising heresthetic seeks to struggle against a widely held position by dividing and forming sects out of what might otherwise be a dominant and homogenous group.

Like all arts, heresthetic requires practice in order for one to become a 'master'. Therefore, the 'vicarious experience of instruction' takes on particular importance for the aspiring heresthetician (Riker 1986, ix). This pedagogical endeavour generally starts by identifying a surprising political result, then using this context to explicate on the strategic contribution of the heresthetician (McLean 2002). The public policy we have chosen to analyse is local government amalgamation which is a reform 'almost certain to engender community angst' and often leads to political losses (XXX and YYY 2017a, 37). The main heresthetic manoeuvre we wish to demonstrate is manipulation of dimensions (ways of thinking about a political issue which tap into discrete preferences and tastes). To do so, we focus on two of the principal dimensions by which local government amalgamation have been 'sold' Efficiency (which is defined by economists as the ratio of inputs to outputs and is often raised as a means to attaining an end of greater financial sustainability) and scale (often promoted in terms of size dependent attributes, such as a local government's capacity to undertake delivery of major infrastructure and regional planning, ability to partner and advocate with higher tiers of government, strengthening of regional identities and depth of resources to cope with unexpected shocks). We contend that the former concept is empirically contestable (that is, open to rhetorical challenge) and amenable to precise definition, whilst the latter largely defies empirical challenge. This has important implications for the heresthetician who must struggle against what appears to be, in many countries, a dominant preference against the proposition of local government amalgamation (YYY and XXX 2017). To achieve this goal, the heresthetician must divide what is prima facie a homogenous group of amalgamation sceptics by introducing new dimensions which speak to latent attitudes and tastes (Riker 1986).

We also innovate by developing a heuristic which might guide the decision making of prospective heresthetician seeking to manipulate on dimensions. In particular, the heuristic that we offer focuses on carefully controlling the costs (including 
opportunity, contingency and legacy costs) faced by herestheticians and opponents. The resultant 'dimension heuristic' is consistent with our pedagogical intent and the broader aim of the heresthetic research program to 'supply valid and reliable tools' (Rosenthal 2014, 176). That is, the purpose of our work is to demonstrate what could be done in order to enhance the chances of success for future proponents of local government amalgamations, not merely to dissect historical events. In this regard, it is important to note that one of the big challenges facing any proponent of local government amalgamations is that the 'winners' from this public policy struggle are likely to experience very small gains which are dispersed among many, whilst the 'losers' are likely to experience a profound 'loss' and are concentrated and thus more easily mobilized for advocacy regarding their position. It is therefore imperative for architects of local government amalgamations, in particular, to have a good understanding of heresthetic if they are to stand any chance of successfully 'selling' the said reforms.

The balance of this journal article is organised as follows. First we extend the heresthetic literature by exploring how heresthetic and rhetoric are connected, the costs associated with particular decisions, and the importance of considering potential opposition responses in the strategic decision-making process. Next we review the dimensions of 'efficiency' and 'scale' with a view to emphasizing the utility of each for a heresthetician seeking to win in a struggle for amalgamation. We then compare and contrast the two most recent forced amalgamation programmes in Australia in order to demonstrate the utility of the heuristic developed from theory. We conclude by considering the implications of our heuristic for both prospective herestheticians in other public policy areas and for the heresthetic research agenda. 


\section{A Heuristic for Winning}

It is important to note early on that heresthetic is about rational choice, not moral choice. Unlike it's cousin rhetoric, heresthetic does not rely on the ethos - indeed, Riker notes that devious means will sometimes be employed in order to execute a win but observes that 'however, much some may condemn the..... heresthetic, extraordinary cleverness deserves some reward' (Riker 1986, 76). Unencumbered by any pretence at teaching or exhibiting virtue the heresthetician has a range of manipulations at their disposal, which Riker (1986) organises according to three categories: Agenda control, strategic voting, and dimension control. We agree with McLean $(2002,555)$ that 'historians, politicians and political scientists have always known that log-rolling and agenda manipulation go on', thus suggesting that the third category - dimension manipulation - might prove to be the most interesting and most fruitful avenue for pedagogical purposes. Indeed, Nagel $(1993,157)$ notes that 'the preferred, most frequently attempted heresthetical device is manipulation of dimensions, by which he [Riker] usually means the introduction of a new dimension in order to upset the equilibrium'.

A dimension is a discrete way of looking at a particular matter. For instance, Feiock et al. $(2006,275)$ discuss dimension control relating to local government amalgamation, noting instances of debates framed in terms of 'vague notions of economy and efficiency', racial divisions (and the voice of minority groups), and economic development (notably Feiock et al. 2006 do not refer to financial sustainability at all in their seminal analysis, presumably because financial sustainability is a desired end, not a means to an end). Each dimension is likely to resonate with different groups: Efficiency might prove popular with local government taxpayers who struggle to pay imposts, minority voice dimensions will appeal to minorities and many on the political left, whilst economic development will hold particular interest for business owners and perhaps the unemployed. The 'art' in heresthetic is to probe for a dimension that resonates with a sufficient number of auditors such that the heresthetician might be in a position to realise a win.

\section{Heresthetic and Rhetoric}

Both heresthetic and its classical cousin - rhetoric - are concerned with winning. However, the win is brought about in fundamentally different ways. The rhetorician employs the logos (reasoning to prove a truth or apparent truth), pathos (emotions of the listeners) and ethos (the character or portrayed character of the rhetor) to persuade auditors (Aristotle 2012). This is a costly and risky endeavour because it 'implicitly at least, requires recognition of error' by the auditor (Riker 1990, 54). Indeed, to overcome the natural reticence that most of us feel against admitting that we might have erred, rhetors tend to make exaggerated claims of impending doom and there is a growing body of evidence that such claims can be largely categorized according to a handful of theses (see, for instance, Hirschman 1991; XXX et al. 2016). In particular, proponents of a public policy reform might be expected to resort 
to Imminent Danger (emphasizing the dangers of passivity in the face of looming threats) and Desperate Predicament (a situation so dire as to justify casting caution to the wind) arguments (XXX et al. 2016). By way of contrast doom-like theses of Jeopardy (an argument of unacceptable consequences) and Perversity (a claim that the public policy will produce effects opposite of those which are intended) are common rhetorical ploys of those opposed to disputatious public policy reforms (YYY and XXX 2017).

Heresthetic on the other hand, takes existing preferences as fixed and instead focuses on tapping into latent attitudes, which may accord with the heresthetician's goals. However, heresthetic is rarely entirely divorced from rhetoric: Indeed, rhetoric is often required as a seasoning to make the heresthetic 'palatable' (Riker 1990, 48). Moreover, because heresthetic does not require auditors to change their opinion it can sometimes be a far more cost-effective way of achieving a win.

\section{Costs}

When considering the costs of winning one must go beyond the actual effort and time spent and also consider opportunity costs - the value of alternatives foregone. This is particularly important because of the observation that 'ordinarily a single human being can simultaneously only evaluate a few issues and alternatives' (Riker 1996, 129) - an idea confirmed by educational psychology. Thus, when one dimension is raised it may well prevent the use of other dimensions, or have an impact on the effectiveness of other dimensions. Moreover, when effort is expended in a rhetorical play, to persuade on a given dimension, it would seem to prohibit (or at least make less effective) simultaneous efforts to introduce a new dimension.

The implication for those seeking to turn a likely loss into a win is that there are constraints imposed by opportunity costs which auger against 'continually poking and pushing the world to get the results they want' (Riker in Shepsle 2003, 310). Moreover, it seems to suggest that if a dimension fails to resonate, then the heresthetician might be well advised to quickly discard said dimension in favour of a new approach (in order to avoid exceeding auditor capacity to simultaneously evaluate alternatives), or probe for a complementary dimension (that is consistent with the previous dimension and therefore sums to the adherents which the heresthetician is able to prise off from the dominant sect).

The recognition of the salience of opportunity cost seems to suggest that it is important for the putative loser to know in advance how they might achieve a win. This appears prima facie to be an extraordinary conundrum - to know in advance the result arising from a heresthetic probe or rhetorical ploy would seem to require not only the ability to predict the future of one's own actions, but also the retaliatory actions of one's opponents. However, there are some measures which might be taken to allow the prospective heresthetician to gauge the likely response of auditors and opponents. Principal among these measures is for the putative loser to examine how 
past games have been played - particularly, where games have been played multiple times - and there is a relatively large heresthetic literature employing analytical narratives to dissect such 'historical' surprising results (although little in the context of local government amalgamations; see, for instance, Feiock et al. 2006; Riker $1986^{2}$ ). Secondly, there is the option of employing a focus group to 'pre-test' a heresthetic and the rhetorical seasoning employed to make it palatable. Indeed, Riker (1986) saw the advent of the focus group to be an innovation of great potential for the heresthetician.

It should also be noted that costs have a temporal dimension: That is, in addition to the immediate cost, there may well be a cost incurred down the track. For example, if claims are made in prosecuting a win that could be tested against evidence after the public policy has been implemented, then this represents a contingency cost (which can be defined as costs which only emerge should future events occur). Moreover, the potential for a win to subsequently be reversed, may represent a potential legacy cost (which can be defined as costs which are incurred only when political decisions are subsequently reversed). Both contingency and legacy costs have been largely neglected in the heresthetic literature and correcting this neglect suggests that vision might also be required - not only to set about the activities needed to turn a potential loss into a win in the present, but to also incorporate measures to reduce costs into the future (see, Rosenthal and Doron 2009 for an example of the intertemporal dependency of heresthetic). One way of containing temporal costs is to lock-in a win by executing an irreversible decision - such an act, where it is possible, not only thwarts opponents during the public policy battle, but also protects the legacy of the heresthetician after the victory (Dellepiane-Avellaneda 2012).

However, it would be quite wrong to perceive that costs only introduce constraints onto the heresthetician - opposing a heresthetical manoeuvre also requires opponents to spend time and effort, and forego other alternatives. The clever heresthetician can use this knowledge to their advantage in a number of ways. For instance, the heresthetician can choose dimensions that practically constrain the feasible options of their opponents by raising a dimension that accords with the opponent's ideology or that pre-empts a likely rhetorical foil (Riker 1990). Second, the heresthetician can introduce a dimension through an expert independent 'friend' - or multiple expert friends - that increases the rhetorical cost of opposing the dimension (XXX and YYY 2017). This would seem to be an important improvement to the independent neutral friend of Riker's (1986) camouflaged gerrymander heresthetic. Third, it might also be possible to fix the number of dimensions (Dellepiane-Avellaneda 2012) - by arguing from the outset that only one dimension is salient, dismissing attempts to introduce new dimensions as political games, or setting in place a constrained institutional instrument (for instance a Boundaries Commission with restrictive Terms of Reference) for deliberating on a public policy proposal - thus leaving only the relatively costly option of rhetoric to the opposition. 
Combining these insights yields a heuristic for prospective herestheticians seeking to engineer a political surprise, thus:

[Please insert Figure 1 here]

As illustrated in Figure 1 prior to realising a surprising win on public policy a good deal of preparation is indicated for our prospective heresthetician. First, it seems important to take full advantage of vicarious instruction by reviewing how the game has been played in the past through the lens of heresthetic theory - this 'homework' has the potential to reduce opportunity costs for the proponent. Second, the choice of dimension needs to be made with a view to increasing the opportunity costs for opponents. Third, the heresthetic (and its accompanying rhetorical seasoning) must be prepared and ideally tested. This component of the preparation includes conducting sophisticated empirical proof (where relevant) and ensuring that independent expert friends are on-hand to improve the palatability of the heresthetic dimension. This third component of the heuristic, if done well, will minimise both opportunity costs (getting the seasoning right means the dimension is more likely to succeed) and limit contingency costs (for example, ensuring the evidence is robust leaves little room for analysis that might support contrary positions). Only after this homework has been thoroughly completed should the dimension be launched and the heuristic notes that efforts should be made to fix dimensionality from the outset in order to constrain opponent heresthetic options and hence reduce potential contingency cost (and perhaps also push opponents towards the relatively more costly option of rhetoric). Finally, our heuristic makes plain the importance of locking-in the win as quickly as possible in an irreversible fashion to insure against legacy costs (this might be achieved by forming new local government areas from parts of former councils thus making it 'nigh on impossible to unscramble the egg' (YYY and XXX (2017b, 375)).

We now examine in greater depth two dimensions which are commonly employed as the moving force to sell amalgamation, in order to highlight our observation that all dimensions are not created equal, before applying our heuristic to a comparative study of two disputatious amalgamation programs. 


\section{Two Dimensions of Local Government Amalgamation Debate: Efficiency, and Scale.}

There are two dimensions which are commonly appealed to by herestheticians to 'sell' local government amalgamation. The first, and most common, dimension is efficiency: Specifically the assertion that larger councils can capture economies of scale and thus reduce the unit cost of providing services. Efficiency is generally presented as the means to achieving the teleological end of improved financial sustainability. The second dimension - which has appeared more recently in debates on local government amalgamation in the Antipodes - is an argument that greater scale leads to stronger councils with qualitative benefits including inter alia better regional planning, ability to attract more qualified staff, superior political leadership, and enhanced ability to partner with higher tiers of government (XXX and ZZZ 2016). This second dimension is generally not argued for in terms of the end of financial sustainability probably because there is no systemic evidence that scale alone is associated with financial sustainability (see, XXX and ZZZ 2014). We have chosen these two dimensions because they were appealed to more frequently than any other by amalgamation proponents in recent debates (for instance, both efficiency and scale were the dominant themes in the NSW Government (2015) publication used to launch the forced amalgamation and 'stronger and more efficient councils' were cited in the short media release proclaiming the new local government entities; Baird 2016). Moreover, we reflect on the heresthetic utility of each dimension, before briefly examining how the dimensions were employed in the recent contentious forced amalgamations in New South Wales (NSW) and Queensland.

\section{Selling the Efficiency Dimension}

Technical efficiency is precisely defined by economists to be the ratio of inputs to outputs (after Farrell 1957) but is commonly employed in an imprecise 'cost savings' sense (Faulk et al. 2013). Moreover, it is often taken for granted that 'efficiency' is ipso facto good thus Reinhardt $(1992,3)$ states that 'the fastest way to eliminate a rival policy is simply to brand it inefficient'. Efficiency sans deliberative interrogation probably does resonate strongly with communities - it is certainly the case that few citizens would advocate for inefficient government, not least because this would suggest upward pressure on local government taxation imposts. Yet it is also clear that efficiency is not in any sense the raison d'etre for government - there are many competing aspects of government which one might well value more strongly, such as equity, responsiveness, due process, and democratic accountability (Goodin and Wilenski 1984). Indeed, the presence of competing and compelling values underscores the lessons from the heresthetic literature with respect to the need to fix the dimensionality quickly if it resonates strongly.

The fact that efficiency can be precisely defined and measured means that it is ultimately open to empirical contest. Whether or not empirical contest is forced 
depends largely on how the proponent heresthetician introduces the dimension. For instance, if the efficiency dimension is introduced as merely a claim, without empirical evidence, then opposing parties might be able to simply dismiss the claim of efficiency out of hand (in which case persuasion will largely rely on the ethos). Opponents would, of course, be free to introduce empirical evidence to support their argument (and most people's propensity to put greater store in empirical evidence may mean that evidence-based rhetorical challenges will be more likely to succeed (McCloskey, 1998)), but they are not forced to do so. However, if the proponent heresthetician leads with empirical evidence then it would seem that opponents would be generally forced to counter with their own empirical facts (to overcome the imposing rhetorical challenge of convincing people that they might have erred in their earlier acceptance of evidence-based claims it would seem important to offer compelling empirical evidence, see XXX et al. 2016).

Because claims of efficiency made with empirical proof largely dictate empirical refutation the clever heresthetician can increase the opportunity costs for opponent rhetoricians by ensuring that the dimension is introduced by expert friends employing sophisticated modelling that uses long panels of data. To persuade against amalgamation in the face of this kind of evidence requires opponents to make both a compelling argument for why the expert friend ethos should be disregarded, and introduces significant information costs (arising from the need to collect the data and conduct the analysis; see, XXX et al. 2016).

The fact that efficiency claims can be tested empirically also exposes the proponent heresthetician to potential legacy risk. This is because efficiency, amenable to precise economic definition and estimation, can be calculated ex post to assess proponent claims. Once again, it is important to increase the cost of refutation - this can be achieved by extending the projected horizon used to make efficiency claims. For instance, rather than making a generic claim of increased efficiency, one can make a time-specific claim of an efficiency saving (perhaps over ten years or more). Such a claim will, at least, delay refutation and avoid same entirely if the opposition is unable to maintain its ardour over such a lengthy period. Another way of protecting legacy is to suggest that the efficiency savings might be re-invested into better quality assets or services or downward pressure on local government taxation. These claims would be almost impossible to refute because sufficiently detailed financial data is rarely available. However, claims of re-invested efficiency savings do run the risk of drawing attention to the fact that efficiency is little more than a way of exchanging one set of wants for another, and the heresthetician will need to judge whether the risk associated with this rhetorical seasoning is worth the potential mitigation of legacy costs (Goodin and Wilenski 1984)

\section{Selling the Scale Dimension}

Scale can be defined in terms of population size, number of assessable properties, number of local government staff, or geographic size (square kilometres) but is often 
discussed (instead of being defined) in terms of qualities attributed to scale (such as strength, capacity to undertake regional planning and regional advocacy, ability to partner with higher tiers of government, ability to attract more qualified staff and better political representatives) (ILGRP 2013). In many respects the scale dimension can be boiled downed to an assertion that 'bigger is better' (YYY and XXX 2017) and this assertion is likely to resonate strongly given that it is implicitly reinforced every time one is offered the opportunity to 'upsize' one's burger meal or mobile phone plan - or, one's local government. Indeed, the frequency with which marketing agencies appeal to the 'bigger is better' concept is strong evidence of its perceived efficacy (Riker, 1990). Moreover, there is a good deal of evidence to suggest that the bigger is better dictum does resonate strongly in local government amalgamation debates (see, for example, Savitch et al. 2010).

The scale dimension also introduces constraints onto opponent herestheticians. For instance, the scale argument may neutralize much of the opponent 'identity' dimension: More often than not individuals work, shop and live in multiple local government areas - if pressed to assert an identity, (for instance when asked where they live by a person from overseas), said individuals may nominate the larger regional identity (for example, 'Sydney'), rather than the specific local government area (perhaps 'Randwick'). Thus, when scale is associated with the functional area in which the individual actually operates, the concordance may resonate strongly and make the identity dimension seem incongruous and thus practically constrain the feasible set of dimensions open to opposing herestheticians. Scale arguments can also be framed in terms of internalising spill-overs - which is an inherently appealing concept on equity grounds - and thus thwart another potential opposition heresthetic (equity). This suggests that the rhetorical seasoning accompanying the scale dimension might emphasise functional identity and by so doing, it might be possible to practically constrain opposition options.

It also seems to be the case that the scale argument - because of the multiple ways in which size can be conceived to improve outcomes - can be 'sold' by multiple 'friends'. For instance, property developer lobbies can point to more affordable housing that might result from streamlined development planning rules; examples of major regional infrastructure brought to fruition by previously amalgamated large regional local governments can be used as 'proof' that scale matters; and, politicians and bureaucrats from previously amalgamated councils may be pressed in to service to reflect upon the higher calibre of individuals which the larger entity has been able to attract (it would seem that they would have a vested interest in promulgating this claim).

As we have noted, the heresthetician employing scale to sell local government amalgamations is immune from the risk of empirical refutation - the fact that amalgamation will increase scale is beyond dispute. This fact also means that there are relatively few contingency costs associated with the dimension and limited risks to legacy. However, the ability to define scale in terms of its multiple attributes 
opens the heresthetician up to the risk that auditors will be incapable of simultaneously evaluating all the arguments, and therefore dismiss it as background noise. Herestheticians might therefore be well advised to limit the number issues that they raise in relation to this dimension to ensure that the inherent appeal of bigger is better isn't lost in a flurry of reasons for why it might so (recalling the lessons from educational psychology regarding the capacity of the human mind).

[Please insert Table 1 here]

In sum, the contrast between efficiency and scale demonstrates that all dimensions are far from created equal when viewed from the prospective of a heresthetician seeking to engineer a win on the matter of local government amalgamation. We now briefly examine how these dimensions were employed through the lens of our heuristic, by way of contextual exemplar. 


\section{Efficiency and Scale in Australian Forced Amalgamations}

The two most recent forced amalgamation programs (Queensland and New South Wales) can give us a good insight into the importance of the various elements of the heuristic that we have discussed thus far, for structuring the world in such a way that one might win on the vexatious matter of local government amalgamation. Notably, neither amalgamation can be considered an unmitigated success, and given Australia's heavy reliance on amalgamation as the principal instrument for addressing financial sustainability woes (there are pressures in Tasmania and South Australia for further amalgamations and the NSW government continues to avoid ruling out future efforts), the pedagogical need for prospective proponents seems urgent. Unsuccessful amalgamation programmes subject communities, state and local governments to great pecuniary, political and human costs and it is thus important to optimise the chances of success once the decision is taken to pursue amalgamations. The main players in both programs were essentially the same: Proponents of amalgamation were the incumbent state governments, and opponents of amalgamation were the local governments (particularly elected representatives and executives who stood to lose the most), and the political opposition party who were presented with an opportunity to derive political capital from the events. We first briefly review how the key elements of our heuristic transpired in Queensland in 2007, before turning to the NSW case (2012-2016) that might have benefitted from 'homework' derived from the Queensland experience.

\section{Queensland Forced Amalgamation}

The Queensland amalgamation program formerly commenced with the establishment of the Local Government Reform Commission (LGRC), in April 2007, which was a nominally independent expert panel (although it included Labor party powerbroker Terry Mackenroth who had been the Deputy Premier and Treasurer just two years prior for the incumbent government). Just ten weeks after its establishment the LGRC $(2007,13)$ handed down its recommendation to reduce the number of councils from 157 to 73, which the incumbent Labor government endorsed 'lock stock and barrel' (Beattie and Fraser 2007). The final report of the LGRC had a relatively large focus on efficiency (as a pathway to financial sustainability) with 32 mentions of the term compared with just nine references to scale, although no robust empirical evidence was tendered in the final LGRC (2007) report for the claim that amalgamation would enhance efficiency. The incumbent state government chose to emphasise the dimension of scale (and strength attendant on scale) in its media release response to the LGRC report, and made no specific mention of efficiency at all (Beattie and Fraser 2007). The legislation was passed through Parliament on the $10^{\text {th }}$ of August, 2007 - less than four months after the commencement of the program. All of the proposed amalgamations proceeded as planned.

Opponents of the amalgamation accused the state government of trashing their democratic rights, threatened litigation, and appealed to the Prime Minister to 
intervene (through plebiscites designed to embarrass the state government; Moore 2007)). In addition the political opposition promised to allow de-amalgamations in the event that they were later able to form government - a promise that ultimately resulted in four de-amalgamations in January, 2014 (De Souza et al. 2014). Thus, whilst proponents were able to execute all of the amalgamations they planned, the programme cannot be considered an unmitigated success due to the legacy costs borne.

\section{New South Wales Forced Amalgamation}

The NSW forced amalgamation program can be traced back to May 2012 when the Independent Local Government Review Panel (ILGRP) was established. The ILGRP undertook extensive consultations and released a number of briefing documents prior to its final report which detailed 'preferred option' amalgamations in October 2013. The ILGRP (2013a) report raised both efficiency and scale dimensions as arguments for amalgamation (citing the former 56 times and the latter 17 times). The incumbent Liberal National coalition government then commenced a formal process of gathering evidence on efficiency (despite the fact that consultation documents suggest it initially resonated strongly, ILGRP 2013b), financial sustainability and scale in September 2014 - and pursued both dimensions (efficiency and scale) in its formal response to the ILGRP report (mentioning efficiency three times and scale twice). The evidence gathering process - which first asked councils to self-assess according to seven financial ratios (including an efficiency ratio) and an adequate scale and capacity criteria, and then engaged expert brands (Ernst \& Young and KPMG) to redo the work - elicited a Ministerial proposal for forced amalgamations in December 2015. This forced amalgamation proposal made seven mentions of efficiency (quantifying the projected savings) and four mentions of scale, demonstrating that both dimensions were actively pursued by the state government proponents of amalgamation. Notably, the media release announcing that twenty out of the forty-seven proposals had gone ahead, issued on the 12 of May 2016, made just two references to efficiency and no explicit mention of scale.

Opponents of the amalgamations in NSW accused the state government of trashing their democratic rights, threatened litigation, and in some cases pursued litigation. Opponents also actively contested empirical claims of efficiency in the media and in the Courts (Visentin and Saulwick 2017). The state political opposition made an immediate pledge to allow de-amalgamation in the event that they subsequently gained office, and have since repeated the pledge a number of times which suggests they believe it to be efficacious (McNally 2016).

[Please insert Table 2 here]

Comparison of Approaches to Heuristic.

Neither amalgamation episode can be considered an unmitigated success (although at least the program was fully implemented in Queensland), which means that we 
simply do not have an exemplar of structuring the world so that one can win, and keep winning, on the vexatious matter of local government amalgamations. However, comparison of the key facts from each case can provide us with some assurance as to the validity of the theoretical model that we built earlier.

A key concept that we extracted from the heresthetic literature relates to the importance of doing one's homework diligently to increase costs for opponents. In the case of NSW, the government had a relatively recent example of how the game had been played before from which they might have taken some important lessons. In particular, the speed with which the Queensland amalgamations had been executed, that had been credited with 'forestall[ing] the mobilisation of effective opposition', was a lesson that might have reduced contingency costs considerably had it been heeded in NSW (Dollery et al. 2011, 612). In similar vein, a student of previous amalgamations would have been well aware that litigation might be threatened, and that state political opposition parties would likely attempt to accrue political capital out of events by pledging the opportunity for de-amalgamations in the event that they subsequently gained office. Indeed, a pledge of de-amalgamation might be considered a near-certain eventuality given that de-amalgamation has no pecuniary cost for the state government (local government ratepayers foot the bill) and can only serve to garner votes arising from the sustained anger that tends to accompany episodes of forced amalgamation (the evidence from the negativity bias literature tells us that people are more likely to act on a loss and that grievances arising from large losses tend to be sticky, Boydstun et al. 2017). As we have seen, failure to do this homework in NSW resulted in significant contingency and likely legacy costs being incurred.

Another important component of a heresthetician's homework relates to choosing an appropriate heresthetic dimension - preferably one that constrains options for opponents. Notably in both states, the Panels recommending amalgamations made reference to both efficiency and scale in their final reports. Thus state government amalgamation proponents could easily have adopted one or both of the dimensions in their final pitch to stakeholders. In Queensland the dimension chosen was scale, whilst in NSW both scale and efficiency were pursued. As we noted earlier, scale defies empirical contestation and can neutralise identity and equity dimensions, whilst efficiency claims can be contested although the costs of doing so can be amplified by clever herestheticians. Indeed, ensuring that one has sophisticated empirical evidence with appropriate rhetorical seasoning is the last part of the heresthetician's homework and it is quite evident that neither group of proponents attended to this component. Failure to do this homework in NSW resulted in significant opportunity and contingency costs being incurred, but in Queensland these potential costs seemed to have been mitigated by the speed of execution.

Once a heresthetician's homework has been satisfactorily completed the dimension should be launched in a manner that reflects the need to fix dimensionality. In Queensland, the speed with which the state government amalgamation proponents 
endorsed and executed the amalgamations, in fact, served to fix dimensionality (because opponents were simply not given time to garner contrary evidence or fully develop new dimensions). By way of contrast, in NSW opponents were provided with ample time to develop new dimensions and provide contrary evidence. Ironically this time came as a result of the NSW state government's tortious efforts to develop empirical evidence to support the claims of efficiency (firstly through local government self-assessments and later through expert brands including Ernst \& Young and KPMG (see XXX and YYY 2017). In neglecting to do their homework before launching the heresthetic dimension, but deciding to complete it as a belated afterthought, the NSW amalgamation proponents effectively shifted the burden of opportunity cost from their opponents to themselves. Otherwise stated, it was worse than providing no empirical evidence at all, because the time taken to belatedly do so provided opponents with the opportunity to marshal compelling contrary evidence and thus created contingency costs for amalgamation proponents forced to defend the evidence (Visentin and Saulwick 2017; Gladstone, 2016). Failure to fix dimensionality in NSW opened proponents up to both rhetorical (disputing the efficiency claims with alternate expert brands; XXX and YYY 2017) and heresthetic reprisals (introducing the legal dimension), resulting in both the failure to increase opportunity costs for opponents and the incursion of significant contingency costs.

The final and crucial step for the heresthetician is to lock-in the win as quickly as possible in an irreversible fashion. There is a subtle but important difference between structuring the world so that one can win, and actually winning akin to the difference between a great schmooze and actually ringing up the sale. As evidenced in these case-studies fast execution resulted in all of the proposed amalgamations proceeding, whereas long and tortious execution resulted in less than half of the proposals proceeding (due to mounting contingency costs which ultimately ended in political failure). However, amalgamation proponents in both states failed to protect their legacies by ensuring that all of the amalgamations were irreversible. The most expedient way to do this is to assemble new local government entities out of parts of former councils, thus destroying all hope of returning to former identities. The legacy cost of failing to do this in Queensland was four de-amalgamations - in NSW it is still too early to assess the final cost but given the pledge of the state political opposition it is likely that a legacy cost will be ultimately born.

We now conclude by considering the implications of our heuristic for both prospective herestheticians in other public policy areas and for the heresthetic research agenda. 


\section{Concluding Remarks}

The major contribution of this work is to draw attention to both the importance of costs and dimension to prospective herestheticians. Specifically we note the saliency of opportunity costs (which can be mitigated by doing ones homework with respect to how the game has been played before and preparing proofs and 'expert friends' in advance), contingency costs (which might be limited by carefully constructing evidence and also through fixing the number of dimensions), and legacy costs (which can be constrained by locking-in the win in an irreversible fashion). We also draw attention to the fact that not all dimensions have the same potential costs and opportunities associated with them. In sum, our heuristic emphasises the importance of doing one's homework and considering all dimensions in terms of heresthetic potential prior to trying to engineer a surprising political win.

Most of the principles illustrated in our heuristic and subsequent analysis of the NSW and Queensland local government amalgamations would seem to apply equally to any field of public policy. For instance, it is almost always the case that the game has been played before (in one's own jurisdiction or in a jurisdiction abroad), that there are different dimensions from which the heresthetician might choose (that hold different potential costs and benefits) and that the heresthetic can be tested in advance through focus groups and the like (which requires one to prepare ones 'proof' and 'expert friends' in advance, which in and of itself would be a beneficial outcome of applying our heuristic). Thus the importance of what could be classified as doing ones homework - the first level of our heuristic - would seem to apply to any public policy context (be it local government amalgamation, changes to school funding, changes to taxation policy or just about anything else). Similarly the desirability of fixing dimensions seems universal, although the number of available dimensions would seem to depend on the particular public policy. Only when it comes to locking-in the win in an irreversible fashion might the aspiring heresthetician be unable to faithfully follow the heuristic (for example funding formulas and tax changes can always be reversed), although the desirability of protecting legacy means that serious attention should always be given to same.

One area for future research arising from our work will be to test the rhetorical seasoning of multiple brands and empirical evidence on representative samples of the community (the apparently neglected focus groups from FFTF). Experimental evidence of this kind would allow the heresthetician to better grasp the importance of rhetorical seasoning in heresthetic manoeuvres. In similar vein, comparing public policy successes and failures in similar institutional milieus offer 'natural experiment-like' conditions which might cast further light on the relative importance of the heresthetic's presentation to its success. Further work might also look into why political actors, in particular, choose rhetorical rather than heresthetic approaches - specifically, whether these decisions are contingent on ideology, media activity, or practical constraints imposed by proponent herestheticians who have studied the game or otherwise exercised extraordinary vision. Indeed, questions 
about the conditions which make heresthetic or rhetoric a rational choice still seem to be far from determined in the literature.

In sum, well over three decades on from Riker's seminal work, there is still much to be done before we can fully understand why some public policy sales are surprising successes and others predictable (but perhaps avoidable) failures and we thus commend this research programme to our peers.

\section{Notes}

1. We acknowledge that other dimensions exist - however, our concern is with the two dimensions most commonly employed to sell amalgamation. The lessons we deduce regarding the factors which make one dimension more desirable than another, can be applied beyond the pair of exemplars.

2. There are countless narratives on local government amalgamation (that employ empirical and other frameworks) and prospective herestheticians, having mastered heresthetic concepts, may also be able to glean important lessons from reviewing same (see, for example, YYY and XXX 2017). 


\section{References}

Aristotle. 2012. Aristotle: The Art of Rhetoric. London: Collins Classics.

Baird, Mike. 2016. Media Release: 19 New Councils Created in NSW Today. Sydney: NSW Government.

Beattie, Peter, and Andrew Fraser. 2007. Premier Welcomes Local Government Reform Report. Brisbane: Queensland Government.

Boydstun, Amber, Alison Ledgerwood, and Jehan Sparks. 2017. "A Negativity Bias in Reframing Shapes Political preferences Even in Partisan Contexts." Social Psychological and Personality Science, DOI: 10.1177/1948550617733520: 1-9.

Dellepiane-Avellaneda, Sebastian. 2012. "Gordon Unbound: The Heresthetic of Central Bank Independence in Britain.” British Journal of Political Science 43: 263293

De Souza, Simone, Brian Dollery, and Michael Kortt. 2014. "De-Amalgamation in Action: The Queensland Experience.” Public Management Review 17(10): 14031424.

Dollery, Brian, Michael Kortt, and Bligh Grant. 2011. "A Normative Model for Local Government De-Amalgamation in Australia." Australian Journal of Political Science 46(4): 601-615.

Farrell, Michael J. 1957. "The Measurement of Productive Efficiency." Journal of the Royal Statistical Society 120(3): 253-290.

Faulk, Dagney, Pamela Schaal, and Charles Taylor. 2013. "How Does Local Government Amalgamation Affect Spending? Evidence from Louisville, Kentucky." Public Finance and Management 13(2): 80-98.

Feiock, Richard, Jerred Carr, and Linda Johnson. 2006. "Structuring the Debate on Consolidation: A Response to Leland and Thurmaier." Public Administration Review, March/April: 274-278.

Gladstone, Nigel. 2016. "NSW Council Amalgamation Costs Don't Add Up Experts Say and Government Won't Release Costings.” The Daily Telegraph, July 20.

Goodin, Robert, and Peter Wilenski. 1984. "The Logical Underpinnings of Administrative Principles.” Public Administration Review 44(6): 512-517.

Hirschman, Albert. 1991. The Rhetoric of Reaction: Perversity, Futility, Jeopardy, Cambridge: Belknap Press of Harvard University Press

ILGRP [Independent Local Government Review Panel]. 2013a. Revitalising Local Government: Final Report of the NSW Independent Local Government Review Panel. Sydney: ILGRP. 
ILGRP [Independent Local Government Review Panel]. 2013b. Stage Three Consultations: Summary of Community Submissions. Sydney: ILGRP.

LGRC [Local Government Reform Commission]. 2007. Report of the Local Government Reform Commission. Brisbane: LGRC.

McCloskey, Deirdre. 1998. The Rhetoric of Economics. Madison: University of Wisconsin Press.

McLean, Iain. 2002. "William H. Riker and the Invention of Heresthetic(s)." British Journal of Political Science 32(3): 535-558.

McNally, Lucy. 2016. "NSW Opposition Promises to Reverse Council Amalgamations if Elected." ABC 13 May 2016. http://www.abc.net.au/news/201605-13/nsw-opposition-promises-reverse-council-mergers-if-elected/7410666.

Moore, Tony. 2007. "Referendum on Council Mergers." Brisbane Times 7 August. https://www.brisbanetimes.com.au/news/queensland/referendum-on-councilmergers/2007/08/07/1186252689462.html.

Nagel, Jack. 1993. "Heresthetics and Political Stability: Richard Seddon and the Art of Majority Rule.” British Journal of Political Science 23(2): 139-174.

NSW Government. 2015b. Local Government Reform: Merger Impacts and Analysis. Sydney: NSW Government.

Reinhardt, Uwe. 1992. "Reflections on the Meaning of Efficiency: Can Efficiency be Separated from Equity?" Yale Law \& Policy Review 10(2): 302-315.

Riker, William H. 1986. The Art of Political Manipulation. New Haven: Yale University Press.

Riker, William. H. 1990. "Heresthetic and rhetoric in the spatial model." In Advances in the Spatial Theory of Voting, Hinich J. Enelow, 45-65. New York: Cambridge University Press.

Riker, William H. 1996. The Strategy of Rhetoric: Campaigning for the American Constitution. New Haven: Yale University Press.

Rosenthal, Maoz. 2014. "Policy Instability in a Comparative Perspective: The Context of Heresthetic". Political Studies 62: 172-196.

Rosenthal, Maoz, and Gideon Doron. 2009. "Israel's 1993 Decision to Make peace with the PLO and How Political Losers (this Time) Became Winners." International Negotiation 14: 449.474

Savitch, H. V., Ronald Vogel, and Lin Ye. 2010. "Beyond the Rhetoric - Lessons from Louisville's Consolidation." American Review of Public Administration, 40(1): $3-28$. 
Shepsle, Kenneth. 2003. "Losers in Politics (And How They Sometimes Become Winners)." Perspectives on Politics 1(2): 307-315

Vine, W.E. 1940. Vine’s Expository Dictionary. Virginia: Mac Donald.

Visentin, Lisa, and Jacob Saulwick. 2017. "Blow to Berejiklian Government's Council Mergers as Court Rules Against KPMG Report Secrecy." The Sydney Morning Herald, March 27. URL: https://www.smh.com.au/national/nsw/blow-toberejiklian-governments-council-mergers-as-court-rules-against-kpmg-reportsecrecy-20170327-gv754p.html. 
Table 1. Comparison of Efficiency and Scale Dimensions

\begin{tabular}{|c|c|}
\hline Efficiency & Scale \\
\hline Can be empirically contested. & Defies empirical contestation. \\
\hline $\begin{array}{l}\text { Can introduce constraints onto } \\
\text { opponents if evidence and expert brands } \\
\text { employed. }\end{array}$ & $\begin{array}{l}\text { Inherently constrains identity and equity } \\
\text { dimensions. }\end{array}$ \\
\hline Can be sold by expert brands. & $\begin{array}{l}\text { Can be sold by multiple friends, } \\
\text { including experts. }\end{array}$ \\
\hline $\begin{array}{l}\text { Potential contingency and legacy costs } \\
\text { if claims tested. }\end{array}$ & $\begin{array}{l}\text { Little potential contingency and legacy } \\
\text { costs because claims defy testing. }\end{array}$ \\
\hline
\end{tabular}

Table 2. Comparative Analysis of Heresthetic Moves in Queensland and New South Wales

\begin{tabular}{|c|c|c|}
\hline & Queensland & New South Wales \\
\hline $\begin{array}{l}\text { Dimension pursued by } \\
\text { Government }\end{array}$ & Scale. & Efficiency and scale. \\
\hline Rhetorical Seasoning & $\begin{array}{l}\text { Linking scale to vague } \\
\text { notions of strength. }\end{array}$ & $\begin{array}{l}\text { Empirical proof of } \\
\text { efficiency by self- } \\
\text { assessment and expert } \\
\text { brands. }\end{array}$ \\
\hline $\begin{array}{l}\text { Efforts to fix } \\
\text { dimensions }\end{array}$ & $\begin{array}{l}\text { Quick implementation ( } 4 \\
\text { months) that curtailed } \\
\text { public debate. }\end{array}$ & $\begin{array}{l}\text { Little attempt to fix } \\
\text { dimensions over } 4 \text { years. }\end{array}$ \\
\hline Opponent moves & $\begin{array}{l}\text { Threat of litigation; call for } \\
\text { plebiscite; promise of de- } \\
\text { amalgamation. }\end{array}$ & $\begin{array}{l}\text { Threat and actual } \\
\text { litigation; empirical } \\
\text { evidence refuting } \\
\text { efficiency claims; } \\
\text { promise of de- } \\
\text { amalgamation. }\end{array}$ \\
\hline $\begin{array}{l}\text { Locking-in win quickly } \\
\text { in an irreversible } \\
\text { fashion }\end{array}$ & $\begin{array}{l}\text { Less than } 4 \text { months, but } \\
\text { little effort to protect } \\
\text { against reversal. }\end{array}$ & $\begin{array}{l}4 \text { years and little effort to } \\
\text { protect against reversal. }\end{array}$ \\
\hline Success? & $\begin{array}{l}\text { All proposals executed, but } \\
\text { four subsequent de- } \\
\text { amalgamations. }\end{array}$ & $\begin{array}{l}\text { Less than half of the } \\
\text { proposals executed, and } \\
\text { de-amalgamation remains } \\
\text { a live option. }\end{array}$ \\
\hline
\end{tabular}


Page 22 
Figure 1. A Heresthetic Heuristic for Winning

Study and
Understand How
the Game Has Been
Played Before

$+$\begin{tabular}{|c|c|}
\hline $\begin{array}{c}\text { Choose a Dimension } \\
\text { that Constrains } \\
\text { Opposition Options } \\
\text { and is Difficult to } \\
\text { Foil }\end{array}$ & $\begin{array}{c}\text { Prepare the rhetorical } \\
\text { seasoning - including } \\
\text { empirical evidence, } \\
\text { expert brands or expert } \\
\text { friends }- \text { and test. }\end{array}$ \\
\hline
\end{tabular}

Launch the Heresthetic Dimension in a Manner that Reflects a Need to Fix Dimensionality

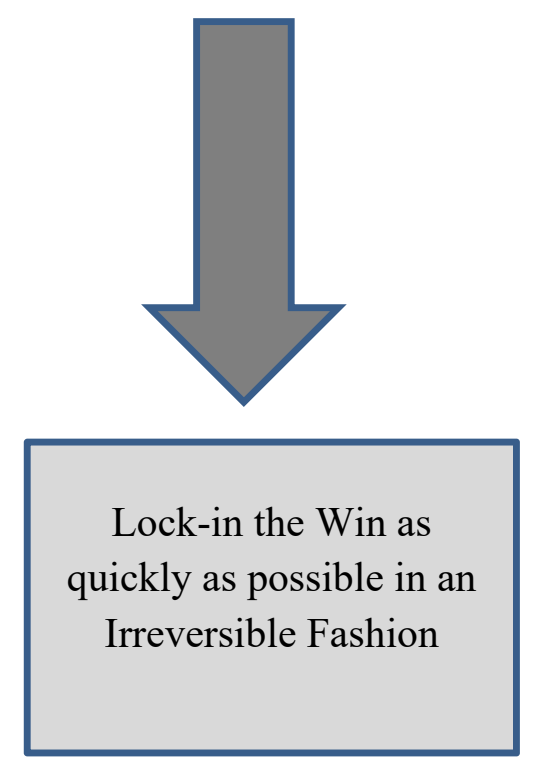

